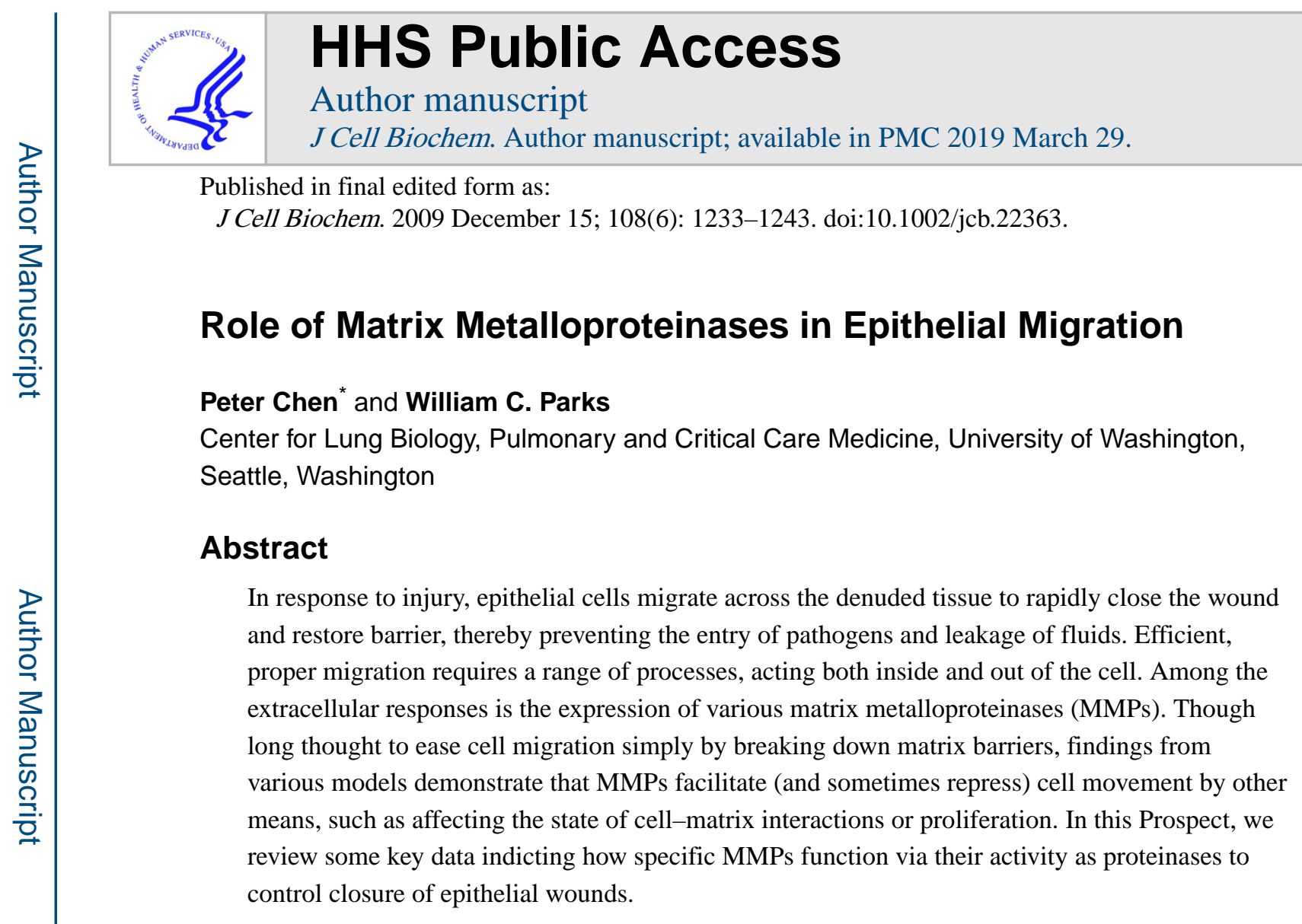

\title{
Keywords
}

EXTRACELLULAR MATRIX; INTEGRIN; ADHESION; MIGRATION

\begin{abstract}
Avariety of developmental, homeostatic, reparative, and disease processes involve, if not depend on cell migration. For example, during embryogenesis, gastrulation, and organogenesis could not occur without the proper temporospatial regulation of the movement specific progenitor cells [Montell, 2008]. As part of normal immune surveillance, various leukocytes constantly migrate in and out of tissues. Likewise, the inflammatory and wound healing response after injury, inclusive of scarring and re-epithelialization, are dependent on the movement and trafficking of a variety of resident and infiltrating cell types.

As a consequence of being placed at the interface to an environment filled with things that can infect and harm, epithelial surfaces, such as the epidermis of skin and the mucosal lining of lungs, kidney tubules, GI tract, and other organs, are subjected nearly constantly to some degree of injury. Hence, these tissues are particularly reliant on cell migration to heal injuries and to re-establish as quickly as possible a barrier that quite importantly separates the pristine internal body from a rather unsanitary outside world. In response to injury-that is, denudation of an epithelial layer due to abrasion, trauma, infection, or cell deathepithelial cells at the wound edge lose their stationary, tissue-specific differentiated phenotype as keratinocytes in skin, hepatocytes in liver, enterocytes in the gut, etc., and take on a pro-migratory phenotype characterized by a lost of cell-cell contacts and expression of
\end{abstract}

*Correspondence to: Dr. Peter Chen, MD, Center for Lung Biology, University of Washington, 815 Mercer Street, Seattle, WA 98109. petechen@uw.edu. 
various intracellular, transmembrane, and secreted proteins that function in cell motility. As a consequence of these changes, an injury-responsive epithelial cell resembles (from the investigator's perspective) a motile fibroblasts. Hence, the term epithelial-to-mesenchymal transformation (EMT) is applied to epithelial cells activity engaged in wound closure [Lee et al., 2006]. However, with few exceptions, gastrulation being most notable, the transformation is neither complete nor permanent. Once epithelial integrity is reconstituted, the migratory program ceases, and the epithelium returns to a differentiated state characteristic of the tissue in which it resides.

Re-epithelialization, however, does not always proceed smoothly, and pathological conditions (e.g., tumor invasion and metastasis, chronic inflammation, fibrosis, and more) arise when an injured epithelium either cannot repair or lose the contextual controls that shut down the migration process [Ridley et al., 2003]. Thus, understanding the determinants of re-epithelialization is relevant to understanding development, tissue repair, and disease pathogenesis.

Matrix metalloproteinases (MMP), a family of extracellular endopeptidases, are often thought to facilitate migration and metastasis by breaking down barriers formed by extracellular matrix (ECM), but clear demonstration of such a role for MMPs is limited to only a few members [Parks et al., 2004; Sabeh et al., 2009a,b]. Other MMPs do function in migration with no apparent activity against ECM proteins, and several others have no demonstrated role in controlling cell movement. In this review, we discuss how specific MMPs function in re-epithelialization with an emphasis on normal wound repair.

\section{EPITHELIAL CELL MIGRATION}

Before we move on to MMPs, we need to discuss some features of epithelial migration, specifically how these cells cover and repopulated damaged tissue during normal wound repair. Mechanisms of cell migration have predominantly been studied in culture models using single cells, typically on two-dimensional surfaces. Although compelling data now indicate that how cells move on 2D substrates is distinct from how they migrate within 3D matrices, this important distinction is likely relevant to cells that move through tissues in vivo, such leukocytes, fibroblasts, smooth muscle cells, angiogenic endothelial cells, invasive tumor cells, etc. [Hotary et al., 2000, 2003; Chun et al., 2004; Doyle et al., 2009; Sabeh et al., 2009b]. In contrast, during normal wound closure, epithelial cells move across a 2D surface; they do not invade. Thus, we would argue that studying epithelial migration on 2D substrata are relevant experimental models of normal re-epithelialization.

Another important consideration is that injured epithelia migrate while retaining cell-cell contacts, moving as an interconnected sheet of cells [Friedl and Gilmour, 2009], replenished by daughter cells that arise from a proliferation node located slightly behind the wound edge. Careful in vivo ultrastructural observations from many years ago showed that epidermal cells at a wound edge stretch and spread over the denuded surface [Odland and Ross, 1968; Krawczyk, 1971; Gibbins, 1978] and, hence, do not migrate per se. The epithelial cells that do migrate during normal wound repair are the daughter cells that "leapfrog" over the cells at the wound edge and adherent to the underlying ECM. These 
observations were made studying wounded human epidermis, a stratified epithelium, and our lab reported similar findings during re-epithelialization of mucosal wounds in human trachea [Dunsmore et al., 1998], a simple (pseudostratified) epithelium. At the wound edge, tracheal epithelial cells were seen in a single layer, markedly elongated and stretched over the denuded wound bed (Fig. 1). Just behind this monolayer and extending back to the edge of the original wound site, the epithelial cells over the newly covered wound bed were cuboidal and clearly stratified into at least two layers. It is likely that the upper layer of tracheal cells are leapfrogging to extend the wound edge. As has been demonstrated for the migration of individual cells, migrating epithelial cycle through a repetitive process of forward extension and attachment followed by cell contraction and rear release [Lauffenburger and Horwitz, 1996; Kaverina et al., 2002; Farooqui and Fenteany, 2005; Doyle et al., 2009].

These observations on re-epithelialization within tissues underscore the importance of cellcell contacts, particularly adherens and tight junctions, held via homophilic interactions of specific transmembrane proteins [Kaverina et al., 2002]. E-cadherin, the major constituent of the adherens junction, plays a critical role by regulating cell polarity [Desai et al., 2009;

Dupin et al., 2009]. Epithelial surfaces maintain a constant apical/basolateral polarity establishing their orientation based on contacts with neighboring cells and the ECM substratum [Yeaman et al., 1999]. Once injured, the normal contexts for maintaining the apical/basal compartments are lost, and a programmed response reorganizes the cellular machinery to a new front/rear polarity aligned with the direction of migration [Ridley et al., 2003]. Another key element in maintaining polarity is centrisome positioning, which appears to stabilize the direction of cell motion [Ueda et al., 1997].

Migrating epithelial cells share many features of single-cell migration, particularly in the polarization of adhesive contacts. Rac and Cdc42, two members of the Rho family of small GTPases, accumulate at the leading edge of the polarized cell and initiate a cascade of events resulting in actin polymerization that, respectively, drives the formation of lamellipodia and filopodia [Nobes and Hall, 1995]. These cellular protrusions engage the substratum primarily through the integrin receptor, which clusters and recruits adaptor proteins to form the focal complex, thus, providing a platform by which the cell front can advance [Kaverina et al., 2002]. Focal complexes contain many components of the classical focal adhesion and are generally short-lived and turn over while spatially within the lamellipodia or filopodia [Webb et al., 2002]. However, a minority of focal complexes persists and matures into focal adhesions. Focal adhesions are positioned at the termini of stress fibers and act as anchors for cell contraction. Rho, another member of the Rho GTPase family, plays a crucial role in focal adhesion dynamics coordinating maturation, cell contraction, and rear release resulting in a net forward translocation of the cell body.

Dynamic modifications of cell interactions with neighboring cells and the substratum occur during epithelial migration. Changes to cell junction proteins can induce a migratory phenotype [Friedl and Gilmour, 2009]. In addition, because overly tight adhesion can prevent rear retraction, whereas if too loose does not provide the traction needed for forward movement, cell-matrix interactions must be tightly tuned and constantly modulated to allow cells to move [DiMilla et al., 1993]. Indeed, intermediate levels of adhesion maximize migration speed [Gupton and Waterman-Storer, 2006]. Integrins are the primary cell 
adhesion receptors and can modify cell adhesion by changing their avidity (number of receptors) and affinity (integrin activation) [Hynes, 2002]. Remodeling of the underlying matrix can also alter cell adhesion and, in turn, migration [Gill and Parks, 2008]. Because MMPs cleave a number of proteins involved with cell-cell and cell-matrix adhesion, it is not surprising that these proteinases have been implicated in re-epithelialization. Indeed, as discussed modifying the affinity of cell- matrix interactions-either by affect matrix or adhesive proteins-appears to a common means of how MMPs facilitate cell migration.

\section{MATRIX METALLOPROTEINASES (MMPs)}

MMPs comprise a family of 25 distinct extracellular endopeptidases, of which 24 are found in mammals (Table I). They are a clan within the larger metzincin family of proteinases, which includes ADAMs, astacins, and others [Greenlee et al., 2007; Page-McCaw et al., 2007; Ra and Parks, 2007]. To be classified as an MMP, a protein must have at least the conserved pro and catalytic domains (Fig. 2). The prodomain of a typical MMP is about 80 amino acids and contains the consensus sequence PRCXXPD. The catalytic domain contains three conserved histidines in the sequence HEXXHXXGXXH, which ligate the active site $\mathrm{Zn}^{2+}$ (hence, the prefix "metallo") [Bode et al., 1993]. The thiol of the prodomain binds the zinc ion, and this interaction keeps proMMPs in a latent state. To become an active proteinase, this "cysteine switch" must be disrupted, which can occur by various means [Van Wart and Birkedal-Hansen, 1990; Ra and Parks, 2007]. The glutamate residue within the catalytic motif activates a zinc-bound $\mathrm{H}_{2} \mathrm{O}$ molecule providing the nucleophile that cleaves peptide bonds. With the exceptions of MMP7, 23, and 26, MMPs have a flexible proline-rich hinge and a hemopexin-like C-terminal domain (Fig. 2). Other domains are restricted to subgroups of enzymes. For example, four membrane-type MMPs (MMP14, 15, 16, 24) have transmembrane and cytosolic domains. Although individual MMPs appear to serve distinct, non-overlapping function, they share a remarkably similar 3D structure [Massova et al., 1998].

MMPs are secreted or anchored to the cell surface, thereby confining their catalytic activity to membrane proteins or proteins within the secretory pathway or extracellular space. The concept that MMPs act on ECM components arose from the original work of Gross and Lapiere [1962] who isolated a metalloproteinase, now called collagenase-4 (MMP18), with collagenolytic activity from regressing tadpole tails. Thereafter, other secreted metalloproteinases were discovered and shown in vitro to act on collagen or other matrix proteins, leading to the addition of the "matrix" prefix. As a consequence, MMPs were assumed to be the extracellular enzymes responsible for turnover of ECM. However, with the emergence of genetically defined animal models, it became clear that as a family MMPs do not function in bulk ECM turnover or degradation in vivo. Several reports in recent years have demonstrated that MMPs act on a variety of non-matrix proteins, such as cytokines, chemokines, surface proteins, receptors, junctional proteins, and more [Levi et al., 1996; Wilson et al., 1999; McQuibban et al., 2000; Li et al., 2002; McGuire et al., 2003; Stamenkovic, 2003; Page-McCaw et al., 2007; Van Lint and Libert, 2007]. About 10\% of our genome encodes for proteins with a signal peptide, leading to an extensive array of potential MMP substrates. Thus, it is not surprising that MMPs evolved to function in a 
variety of physiologic and disease processes [McCawley and Matrisian, 2001; Stamenkovic, 2003; Parks et al., 2004; Cauwe et al., 2007].

Some MMPs do act on ECM components, but their activity is generally limited to a few matrix proteins. For example, MT1-MMP (MMP14) and MT3-MMP (MMP15) have emerged as physiologic collagenases [Holmbeck et al., 1999; Hotary et al., 2000, 2003; Shi et al., 2008], and matrilysin (MMP7) seems to be the relevant elastase in human macrophages [Filippov et al., 2003]. However, matrix degradation is neither the sole or often predominant function of MMPs. Depending on the enzyme, cell source, and process involved, a given MMP can act on various proteins and, in turn, affect various processes. Thus, although several MMPs do function in migration and invasion, one cannot assume a priori that they do so by acting on matrix. Below we discuss some specific examples where mechanism of MMP action in epithelial cell migration is fairly well described. For some MMPs the target substrate is an ECM component, for others it is not, and a common consequence of MMP action seems to be to alter the affinity of cell-matrix interactions.

\section{MMPs IN EPITHELIAL REPAIR MMP1 (COLLAGENASE-1)}

In wounded human skin, MMP1 is induced in basal keratinocytes as the cells move off of the basement membrane and contact type I collagen in the underlying dermis (Fig. 3) [Saarialho-Kere et al., 1993; Sudbeck et al., 1997]. This inductive response is specifically controlled by ligation of the $a_{2} \beta_{1}$ integrin with dermal collagen [Pilcher et al., 1997], and expression of MMP1 is rapidly turned off once re-epithelialization is complete and the basement membrane begins to reform [Inoue et al., 1995; Sudbeck et al., 1997]. The expression patterns of MMP1 provide a good example demonstrating the important generalization that expression and activity of specific MMPs are confined to specific locations in the wound (for MMP1, the superficial plane of the wound bed) and to a specific stages of repair (re-epithelialization).

The invariable expression of MMP1 by basal keratinocytes in all forms of wounds and the confinement of its expression to periods of active re-epithelialization indicates that this enzyme participates in cell migration. During normal re-epithelialization, keratinocytes migrate along a path of least resistance, dissecting underneath the scab while remaining superficial to the underlying viable dermis and wound bed [Stenn and Malhotra, 1992; Kubo et al., 2001]. Keratinocyte migration on type I collagen is completely stalled by antibodies that specifically block MMP1 activity or if the cells are plated on collagenase-resistant mutant type I collagen [Pilcher et al., 1997]. Although other collagenases, including MT1MMP (MMP14) and MMP13, can make the same cleavage in type I collagen, the blockingantibody studies indicate that the proteolytic activity of MMP1 is required for migration of human keratinocyte on native type I collagen.

Based on the above observations, we proposed that MMP1 provides migrating keratinocytes with a mechanism to maintain their course and directionality in the wound environment during re-epithelialization. Basal keratinocytes constitutively express the $a_{2} \beta_{1}$ integrin on their basolateral surfaces, and in wounds, this receptor accumulates at the forward-basal tip 
of migrating keratinocyte in contact with dermal type I collagen [Pilcher et al., 1997; Dumin et al., 2001]. Because $\alpha_{2} \beta_{1}$ binds native collagen with high affinity, clustering this integrin at contact points would tightly tether keratinocytes to the dermis rendering them unable to migrate. MMP1 aids in dissociating keratinocytes from these high affinity attachments by altering the nature of the collagen matrix and, in turn, its affinity with $\alpha_{2} \beta_{1}$. MMP1 makes a single, site-specific cleavage through the triple helix. At body temperature, the fragments unwind, and $a_{2} \beta_{1}$ binds relaxed collagen with lower affinity than it does native collagen [Staatz et al., 1989]. Thus, by simply making a single cut through the type I collagen triple helix, MMP1 effectively mediates the loosening of the tight contacts keratinocytes initially establish with the dermal matrix, thereby allowing the cells to move forward.

Although MMP1 promotes epidermal wound closure by modulating how cells interact with dermal collagen, at first glance, this appears to be an inefficient process. If keratinocytes migrate over dermal matrix, rather than through it, then why expend the energy to cleave type I collagen? Why would the cells initially adhere to collagen so tightly that cannot move if their objective is to close the wound as quickly as possible? The answer, we believe, is that the process of interacting with and then cleaving type I collagen provides keratinocytes with a mechanism to determine and maintain their directionality during re-epithelialization. Because $\alpha_{2} \beta_{1}$ binds native collagen much more tightly than it binds collagenase-cleaved collagen, this integrin, once loosened by the action of MMP1, would favor re-establishment of high affinity interactions with native, uncleaved collagen. Thus, by repeatedly establishing tight contacts, rapidly loosening this hold by the action of MMP1, and reestablishing new tight contacts keratinocytes use native type I collagen as a "molecular compass" guiding repair over the open wound surface. A similar "rear release" mechanism has been proposed to explain how MMP1 promotes the migration of vascular smooth muscle cells on collagen [Li et al., 2000].

Rodents do not have MMP1 in their genome (Table I), but they do express MMP13

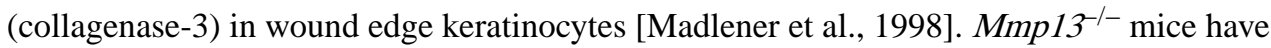
slightly impaired re-epithelialization of cutaneous wounds [Hattori et al., 2009], but how the enzyme functions does not appear to be analogous to the MMP1/ $\alpha_{2} \beta_{1} /$ collagen mechanism in human epidermis. Blocking antibodies against the $\alpha_{2} \beta_{1}$ integrin completely bar keratinocyte migration in culture and in wounded human skin explants [Pilcher et al., 1997; Dumin et al., 2001], demonstrating, as for MMP1, the importance of this receptor for wound repair in human skin. However, closure of skin wounds is not impaired in $a_{2}$ integrindeficient mice [Grenache et al., 2007; Zweers et al., 2007], suggesting that MMP13 may function independently of cell-matrix contacts. As discussed elsewhere [Parks, 2007], another consideration is that the difference in ECM density between human and mouse skin may dictate different proteolytic mechanisms and targets in re-epithelialization among species.

\section{MATRILYSIN (MMP7)}

MMP7 is not expressed in epidermal wounds (Fig. 3) but is prominently expressed in damaged epithelium of all mucosal tissues examined, including lung, gut, kidney, cornea, and more [Saarialho-Kere et al., 1996; Dunsmore et al., 1998; Lu et al., 1999; Li et al., 2002; 
Kure et al., 2003; McGuire et al., 2003; Wroblewski et al., 2003; Surendran et al., 2004; Chen et al., 2008, 2009; Swee et al., 2008]. Thus, the expression of MMP7 is a common response of injured mucosal epithelia. In these tissues, MMP7 is produced primarily by cells bordering denuded regions of the epithelium, analogous to where MMP1 is expressed in wounded skin. Whereas the interaction with dermal collagen induces MMP1 in keratinocytes, cell-matrix contacts do not seem to influence expression of MMP7. The signals that turn MMP7 on in response to injury have not been identified.

Several studies using knock-out mice have reported that MMP7 is required for efficient reepithelialization [Dunsmore et al., 1998; Li et al., 2002; McGuire et al., 2003; Wroblewski et al., 2003; Surendran et al., 2004; Chen et al., 2008, 2009; Swee et al., 2008]. For example, using in vivo and ex vivo models of airway or colon epithelial injury, we found that denuded areas and ulcers persist in $\mathrm{Mmp}^{-1-}$ mice long after injuries have been fully repaired in wildtype animals [McGuire et al., 2003; Chen et al., 2008; Swee et al., 2008]. In fact, $\mathrm{Mmp}^{-1-}$ mice have the most severe wound-repair defect among the MMP knock-out mice generated to date [Parks et al., 2004].

The mechanism by which MMP7 regulates cell migration is an evolving story. Our initial studies found that E-cadherin was a physiologic, in vivo substrate of MMP7 [McGuire et al., 2003], consistent with cell-based observations from others [Davies et al., 2001; Noe et al., 2001]. Because loss of this junctional protein induces a migratory phenotype [Friedl and Gilmour, 2009], we postulated that E-cadherin shedding by MMP7 re-organized cell-cell contacts, thus, promoting cell migration. However, MMP7-mediated shedding of E-cadherin occurs several days after injury [McGuire et al., 2003], at which time re-epithelialization is well under way, if not completed. More recent data suggests that MMP7 shedding of Ecadherin regulates adaptive immunity responses, not epithelial cell migration [Manicone et al., 2009].

We recently reported that MMP7 controls epithelial migration by affecting the affinity of cell-matrix interactions [Chen et al., 2009], a mechanism analogous to how MMP1 functions in human epidermis. Whereas MMP1 acts on an ECM protein (type I collagen), MMP7 sheds a surface protein, syndecan-1, a transmembrane heparan sulfate proteoglycan [Couchman et al., 2001]. Syndecan-1 was of interest because it plays a role in keratinocyte migration [Stepp et al., 2007] and because it is shed by MMP7 from lung epithelium upon injury [Li et al., 2002]. We reported in the lung studies that $\mathrm{KC}$, a potent neutrophil chemokine, is bound to the shed syndecan-1 ectodomain and that releasing this complex is required for neutrophils to advance into the alveolar airspace. Because shedding of syndecan-1 occurs coincidence with the onset of re-epithelialization, we speculated that this proteolytic event is also needed for wound closure. Indeed, we found that syndecan-1 is shed from the lung epithelium by MMP7 after injury in both cell-based and in vivo models [Chen et al., 2009]. Furthermore, wound closure is accelerated in syndecan-1-null cells and tissues and slowed in cells expressing a protease-resistant form of syndecan-1. Moreover, MMP7 shedding of syndecan- 1 attenuates the activation status of the $\alpha_{2} \beta_{1}$ integrin thereby lessening its affinity to matrix substrates and, in turn, releasing restraints to cell migration. Thus, both MMP1 and MMP7 facilitate epithelial migration in different tissues by reducing the affinity of the $a_{2} \beta_{1}$ integrin, but they control the activity of this matrix receptor by 
fundamentally different mechanisms. Whereas MMP1 influences outside-in signaling by altering the ligand, MMP7 affects inside-out signaling by controlling integrin activation.

\section{MMP2 (GELATINASE A) AND MMP9 (GELATINASE B)}

The gelatinases have also been implicated in regulating epithelial cell migration, but the affects are not always consistent among models nor have they all been verified in vivo. For example, exogenous MMP2 added to primary human nasal epithelial cultures promote wound closure [Lechapt-Zalcman et al., 2006], and human mammary epithelial cells supplemented with MMP2 accelerate cell migration by cleaving a repressive peptide from one chain of laminin 332 [Giannelli et al., 1997]. However, a repair or migration phenotype has not been reported for $M m p 2^{-1-}$ mice (Table I). Furthermore, exogenous MMP2 may be added to cultured cells in concentrations beyond that obtained in vivo, leading to cleavage of biologically irrelevant substrates, highlighting the importance of corroborating studies using physiological models [Overall and Blobel, 2007].

Injured epithelia of the eye, skin, gut, and lung express MMP9 [Fini et al., 1996; Legrand et al., 1999; Betsuyaku et al., 2000; Mohan et al., 2002; Castaneda et al., 2005], but its role in repair is somewhat controversial. On one hand, excisional skin wounds heal poorly in

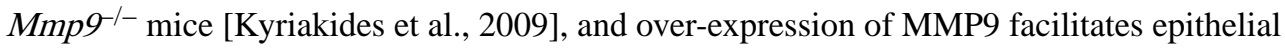
migration in an in vitro wound assay [Seomun et al., 2008]. In addition, Legrand et al. [1999] reported that MMP9 promotes lung epithelial cell migration in vitro potentially by modifying cell adhesion to type IV collagen, and Betsuyaku et al. [2000] found MMP9mediated bronchiolization of injured alveolar surfaces. Similarly, MMP9 has been suggested to be required for smooth muscle cell migration during atherogenesis [Galis et al., 2002]. Although these findings suggest that MMP9 facilitates migration directly, impaired wound closure can arise from other affected processes, such as reduced proliferation. In contrast, others have reported that MMP9 slows migration of an enterocyte cell line [Castaneda et al., 2005] and inhibits the closure of corneal wounds by inhibiting cell proliferation [Mohan et al., 2002]. These disparate findings may indicate that MMP9 does different things in different tissues, and corneal repair is indeed unique.

When expressed by epithelial cells, particularly cancer cells, it is often assumed that MMP2 and MMP9 are functioning to breakdown the basement membrane by degrading type IV collagen. Indeed, these two MMPs were initially called type IV collagenases because they could degrade this abundant basement membrane component in vitro [Collier et al., 1988; Wilhelm et al., 1989]. However, this concept has been challenged (if not, in fact, debunked) by data - largely negative data - with genetically modified mice [Stetler-Stevenson and Yu, 2001; Parks et al., 2004]. Furthermore, as is thoroughly discussed and referenced in a recent review [Rowe and Weiss, 2008], several studies found that MMP2 and MMP9 are actually weak type IV collagenases, and no basement membrane defects have been reported in mice lacking either or both of these proteinases. Although the lack of basement membrane effects can be attributed to redundancy or compensation, the fact that $\mathrm{Mmp}^{2^{-1-}}$ and $\mathrm{Mmp}^{9^{-/-}}$mice do reveal distinct, non-overlapping phenotypes in other processes [Parks et al., 2004; Cauwe et al., 2007] argues that these MMP evolved to carry out specific functions-an argument, we believe, that can be made for all MMPs. So what do MMP2 and MMP9 act on to affect 
migration? Some putative substrates, linked directly or indirectly to migration, have been identified for MMP2 and MMP9 in other systems, such as leukocyte influx and tumor cell invasion [Larsen et al., 2003; Greenlee et al., 2006; Kenny et al., 2008; Vaisar et al., 2009], but these have not been assessed in re-epithelialization. Thus, how these two highly studied enzymes function in normal epithelial repair remains an open question.

\section{MT1-MMP (MMP14)}

By being a transmembrane protein, MMP14, as well as the other membrane-type MMPs, is in an advantageous position to affect cell movement, and its role in promoting migration and invasion of various cell types as been reviewed in detail [Seiki, 2002]. More recently, Weiss and coworkers have demonstrated convincingly that MMP14, via its ability to act as a collagenase, is required for tumor cell invasion into and survival within 3D matrices [Hotary et al., 2003; Sabeh et al., 2009b]. Furthermore, cleavage of syndecan-1, CD44, and laminin-322 by MMP14 speeds migration of various epithelial cells in culture [Koshikawa et al., 2000; Kajita et al., 2001; Endo et al., 2003], suggesting that this enzyme can promote reepithelialization in vivo.

With respect to skin repair, MMP14 is produced by normal keratinocytes in culture or intact skin [Baumann et al., 2000; Krengel et al., 2002; Nagavarapu et al., 2002; Netzel-Arnett et al., 2002], and its overall expression in skin increases in response to injury. However, MMP14 is apparently not actively produced in the epidermis of wounded human or rodent skin (although the protein would still be present) but rather the increased levels in wounds is due to expression by cells in the dermis [Okada et al., 1997; Madlener et al., 1998; Mirastschijski et al., 2002]. Mirastschijski et al. [2004] reported that wound closure is not affected in $\mathrm{Mmp} 14^{-1-}$ mice, but because of the marked fragility of these mice [Holmbeck et al., 1999; Zhou et al., 2000], they could only assess small wounds in the skin of 3-day-old neonates. When they assessed keratinocyte outgrowth from skin explants, they did find a modest reduction in the rate of epiboly from $\mathrm{Mmp}^{14^{-/}}$tissue compared to wild-type skin with no change in proliferation. Similarly, knockdown of MMP14 slows keratinocyte migration [Nagavarapu et al., 2002; Seomun et al., 2008]. Complementary to these findings, Atkinson et al. [2007] reported that airway wounds are slow to heal in $M m p 14^{-1-}$ mice, but they concluded that the enzyme was needed for cell proliferation and not for migration. The substrate(s) that MMP14 acts on to facilitate re-epithelialization in vivo has not been identified, but the cell culture studies mentioned above point to some reasonable candidates.

\section{OTHER MMPS}

Other MMPs, such as stromelysin-2 (MMP10) and epilysin (MMP28), among others, are also expressed by wound edge epithelial cells in various tissues (Fig. 3) [Saarialho-Kere et al., 1994; Okada et al., 1997; Madlener et al., 1998; Vaalamo et al., 1998; Lohi et al., 2001; Saarialho-Kere et al., 2002]. Over-expression of MMP10 by basal keratinocytes led to modest acceleration of wound closure and altered cell-matrix interactions [Krampert et al., 2004]; however, the precise function and substrates of MMP10 and MMP28 have not yet been determined (Table I). Whereas some MMPs are released by cells at the forward edge of migration, others, such as stromelysin-1 (MMP3) and MMP28 are expressed by cells behind the migratory front [Saarialho-Kere et al., 1994; Lohi et al., 2001]. MMP3 does promote 
wound closure in skin, but the effect is apparently secondary to controlling dermal fibroblast contraction [Bullard et al., 1999a,b]. Other MMPs, such as MMP19, 21, and 26, are expressed in intact and/or damaged epithelium [Bister et al., 2004, 2007; Skoog et al., 2009], but no functional data has yet been reported for these enzymes. Mice lacking collagenase-2 (MMP8), a product of neutrophils and some chondrocytes, also have reduced wound closure rates, but this phenotype is thought to occur secondary to excessive inflammation and not to a direct effect on re-epithelialization [Li et al., 2000].

\section{FUTURE PROSPECTS}

Our concepts of what MMPs do in tissues have evolved from the initial discovery as matrix degrading enzymes in the tadpole tail to now being seen as a family of extracellular enzymes that function in controlling a range of cell processes [Brinckerhoff and Matrisian, 2002; Cauwe et al., 2007]. Being proteinases, MMPs affect biologic processes via their ability to cleave or degrade specific protein targets, and most typically, they mediate gain-of-function processing of latent effector proteins on cell surface. Several studies in diverse systems, from re-epithelialization to encephalitis to tumor progression to acquired immunity, have demonstrated that specific MMPs control a variety of processes. To understand MMP function, we need to identify and verify their specific physiologic protein substrates of MMPs.

Although in vitro biochemical assays are useful for showing what a proteinase can cleave, they seldom are reliable for predicating the physiologic substrates that they do cleave in vivo. Still, these techniques have merit, such as for verifying possible substrates [Overall and Blobel, 2007], but they do not duplicate the complexities of the biological processes that restrict and regulate the presentation of an MMP to its substrate [Ra and Parks, 2007]. Therefore, in trying to uncover the true in vivo role of MMPs, physiological models, such as whole animals, tissue explants, organotypic cultures, etc., that mirror biological settings are needed for identifying MMP functions and substrates [Overall and Blobel, 2007; Sabeh et al., 2009b].

Identifying the physiological substrates of MMPs (or other proteinases) is challenging but doable. Hypothesis-driven experimentation has been by and far the most common approach to finding candidate MMP substrates (largely because these were the only strategies available). Close examination of phenotypes in knock-out mice may point to candidates.

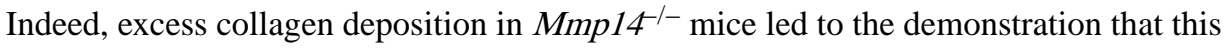
MMP is a physiologic collagenase [Holmbeck et al., 1999], and FasL was identified as a substrate of MMP7 when reduced apoptosis was seen in the prostate glands of castrated Mmp $\mathrm{T}^{-1-}$ mice [Powell et al., 1999]. Substrates can also be identified by less biased approaches. Proteinases bind substrates by exosite regions away from the catalytic domain, and these interactions can be exploited to design affinity approaches, such as yeast twohybrid assay, to find binding partners [McQuibban et al., 2000]. Lately, however, proteomics has emerged as the "way" to find substrates [Guo et al., 2002; Tam et al., 2004; Overall and Blobel, 2007; Doucet et al., 2008; Vaisar et al., 2009]. A basic strategy is to compare the differential proteomes of shed or membrane proteins between wild-type and knock-out cells or tissues. Identifying a manageable list of potential substrates enables one to design further 
confirmatory experiments to verify MMP/substrate interactions in a biological process (e.g., cell migration).

Mapping out exact mechanisms (i.e., substrates) is crucial if any therapeutic potential can be gained where MMPs mediate or are thought to mediate pathology. Because MMPs also serve homeostatic functions, such as wound repair, delineating their role in normal processes is a necessary complement to understanding their function in disease pathogenesis. In addition, recognizing the beneficial role of MMPs provides a point of comparison when studying disease. Therapies must focused on inhibiting the "bad" MMPs that contribute to disease while sparing the activity of the "good" MMPs. As evidenced in clinical trials of broad-spectrum MMP inhibitors in the treatment of advanced carcinomas, non-specific inhibition of many MMPs leads quite disastrous results, likely because the "good" MMPs are blocked along with the "bad" [Coussens et al., 2002]. Thus, future MMP research needs to focus on substrate identification to truly understand biology of specific MMPs in health and disease.

\section{ACKNOWLEDGMENTS}

Our original work discussed in this article was funded by grants from the NIH, the American Lung Association, and the American Heart Association.

Grant sponsor: NIH; Grant sponsor: American Lung Association; Grant sponsor: American Heart Association.

\section{REFERENCES}

Atkinson J, Toennies HM, Holmbeck K, Senior RM. 2007 Membrane type 1 matrix metalloproteinase is necessary for distal airway epithelial repair and keratinocyte growth factor receptor expression after acute injury. Am J Physiol Lung Cell Mol Physiol 293:L600-L610. [PubMed: 17557804]

Balbin M, Fueyo A, Knauper V, Lopez JM, Alvarez J, Sanchez LM, Quesada V, Bordallo J, Murphy G, Lopez-Otin C. 2001 Identification and enzymatic characterization of two diverging murine counterparts of human interstitial collagenase (MMP-1) expressed at sites of embryo implantation. J Biol Chem 276:10253-10262. [PubMed: 11113146]

Baumann P, Zigrino P, Mauch C, Breitkreutz D, Nischt R. 2000 Membrane-type 1 matrix metalloproteinase-mediated progelatinase A activation in non-tumorigenic and tumorigenic human keratinocytes. Br J Cancer 83:1387-1393. [PubMed: 11044366]

Betsuyaku T, Fukuda Y, Parks WC, Shipley JM, Senior RM. 2000 Gelatinase B is required for alveolar bronchiolization after intratracheal bleomycin. Am J Pathol 157:525-535. [PubMed: 10934155]

Bister VO, Salmela MT, Karjalainen-Lindsberg ML, Uria J, Lohi J, Puolak-kainen P, Lopez-Otin C, Saarialho-Kere U. 2004 Differential expression of three matrix metalloproteinases, MMP-19, MMP-26, and MMP-28, in normal and inflamed intestine and colon cancer. Dig Dis Sci 49:653661. [PubMed: 15185874]

Bister V, Skoog T, Virolainen S, Kiviluoto T, Puolakkainen P, Saarialho-Kere U. 2007 Increased expression of matrix metalloproteinases-21 and -26 and TIMP-4 in pancreatic adenocarcinoma. Mod Pathol 20:1128-1140. [PubMed: 17873896]

Bode W, Gomis-Rüth FX, Stockler W. 1993 Astacins, serralysins, snake venom and matrix metalloproteinases exhibit identical zinc-binding environments (HEXXHXXGXXH and Met-turn) and topologies and should be grouped into a common family, the 'metzincins'. FEBS Lett 331:134140. [PubMed: 8405391]

Brinckerhoff CE, Matrisian LM. 2002 Matrix metalloproteinases: A tail of a frog that became a prince. Nat Rev Mol Cell Biol 3:207-214. [PubMed: 11994741] 
Bullard KM, Lund L, Mudgett JS, Mellin TN, Hunt TK, Murphy B, Ronan J, Werb Z, Banda MJ. 1999a Impaired wound contraction in stromelysin-1-deficient mice. Ann Surg 230:260-265. [PubMed: 10450741]

Bullard KM, Mudgett J, Scheuenstuhl H, Hunt TK, Banda MJ. 1999b Stromelysin-1-deficient fibroblasts display impaired contraction in vitro. J Surg Res 84:31-34. [PubMed: 10334885]

Castaneda FE, Walia B, Vijay-Kumar M, Patel NR, Roser S, Kolachala VL, Rojas M, Wang L, Oprea G, Garg P, Gewirtz AT, Roman J, Merlin D, Sitaraman SV. 2005 Targeted deletion of metalloproteinase 9 attenuates experimental colitis in mice: Central role of epithelial-derived MMP. Gastroenterology 129:1991-2008. [PubMed: 16344067]

Cauwe B, Van den Steen PE, Opdenakker G. 2007 The biochemical, biological, and pathological kaleidoscope of cell surface substrates processed by matrix metalloproteinases. Crit Rev Biochem Mol Biol 42:113-185. [PubMed: 17562450]

Chen P, McGuire JK, Hackman RC, Kim KH, Black RA, Poindexter K, Yan W, Liu P, Chen AJ, Parks WC, Madtes DK. 2008 Tissue inhibitor of metalloproteinase-1 moderates airway reepithelialization by regulating matrilysin activity. Am J Pathol 172:1256-1270. [PubMed: 18385523]

Chen P, Abacherli LE, Nadler ST, Wang Y, Li Q, Parks WC. 2009 MMP7 shedding of syndecan-1 facilitates re-epithelialization by altering a $2 \beta 1$ integrin activation. PLoS ONE 4:e6565. [PubMed: 19668337]

Chun TH, Sabeh F, Ota I, Murphy H, McDonagh KT, Holmbeck K, Birkedal-Hansen H, Allen ED, Weiss SJ. 2004 MT1-MMP-dependent neovessel formation within the confines of the threedimensional extracellular matrix. J Cell Biol 167:757-767. [PubMed: 15545316]

Collier IE, Wilhelm SM, Eisen AZ, Marmer BL, Grant GA, Seltzer JL, Kronberger A, He CS, Bauer EA, Goldberg GI. 1988 H-ras oncogenetransformed human bronchial epithelial cells (TBE-1) secrete a single metalloprotease capable of degrading basement membrane collagen. J Biol Chem 263:6579-6587. [PubMed: 2834383]

Couchman JR, Chen L, Woods A. 2001 Syndecans and cell adhesion. Int Rev Cytol 207:113-150. [PubMed: 11352265]

Coussens LM, Fingleton B, Matrisian LM. 2002 Matrix metalloproteinase inhibitors and cancer: Trials and tribulations. Science 295:2387-2392. [PubMed: 11923519]

Davies G, Jiang WG, Mason MD. 2001 Matrilysin mediates extracellular cleavage of E-cadherin from prostate cancer cells: A key mechanism in hepatocyte growth factor/scatter factor-induced cell-cell dissociation and in vitro invasion. Clin Cancer Res 7:3289-3297. [PubMed: 11595727]

Desai RA, Gao L, Raghavan S, Liu WF, Chen CS. 2009 Cell polarity triggered by cell-cell adhesion via E-cadherin. J Cell Sci 122:905-911. [PubMed: 19258396]

DiMilla PA, Stone JA, Quinn JA, Albelda SM, Lauffenberger DA. 1993 Maximal migration of human smooth muscle cells on fibronectin and type IV collagen occurs at an intermediate attachment strength. J Cell Biol 122:729-737. [PubMed: 8335696]

Doucet A, Butler GS, Rodríguez D, Prudova A, Overall CM. 2008 Metadegradomics: Toward in vivo quantitative degradomics of proteolytic post-translational modifications of the cancer proteome. Mol Cell Proteomics 7:1925-1951. [PubMed: 18596063]

Doyle AD, Wang FW, Matsumoto K, Yamada KM. 2009 One-dimensional topography underlies threedimensional fibrillar cell migration. J Cell Biol 184:481-490. [PubMed: 19221195]

Dumin JA, Dickeson SK, Stricker TP, Bhattacharyya-Pakrasi M, Roby JD, Santoro SA, Parks WC. 2001 Procollagenase-1 (matrix metalloproteinase-1) binds the integrin a $2 \beta 1$ upon release from keratinocytes migrating on type I collagen. J Biol Chem 276:29368-29374. [PubMed: 11359786]

Dunsmore SE, Saarialho-Kere UK, Roby JD, Wilson CL, Matrisian LM, Welgus HG, Parks WC. 1998 Matrilysin expression and function in airway epithelium. J Clin Invest 102:1321-1331. [PubMed: 9769324]

Dupin I, Camand E, Etienne-Manneville S. 2009 Classical cadherins control nucleus and centrosome position and cell polarity. J Cell Biol 185:779-786. [PubMed: 19487453]

Endo K, Takino T, Miyamori H, Kinsen H, Yoshizaki T, Furukawa M, Sato H. 2003 Cleavage of syndecan-1 by membrane type matrix metalloproteinase-1 stimulates cell migration. J Biol Chem 278:40764-40770. [PubMed: 12904296] 
Farooqui R, Fenteany G. 2005 Multiple rows of cells behind an epithelial wound edge extend cryptic lamellipodia to collectively drive sheet-driven movement. J Cell Sci 118:51-63. [PubMed: 15585576]

Filippov S, Caras I, Murray R, Matrisian LM, Chapman HA, Jr., Shapiro S, Weiss SJ. 2003 Matrilysindependent elastolysis by human macrophages. J Exp Med 198:925-935. [PubMed: 12963695]

Fini ME, Parks WC, Rinehart WB, Matsubara M, Girard M, Cook JR, Jeffrey JJ, Burgeson RE, Raizman M, Kreuger R, Zieske J. 1996 Role of matrix metalloproteinases in failure to reepithelialize following corneal injury. Am J Pathol 149:1287-1302. [PubMed: 8863676]

Friedl P, Gilmour D. 2009 Collective cell migration in morphogenesis, regeneration and cancer. Nat Rev Mol Cell Biol 10:445-457. [PubMed: 19546857]

Galis ZS, Johnson C, Godin D, Magid R, Shipley JM, Senior RM, Ivan E. 2002 Targeted disruption of the matrix metalloproteinase-9 gene impairs smooth muscle cell migration and geometrical arterial remodeling. Circ Res 91:852-859. [PubMed: 12411401]

Giannelli G, Falk-Marzillier J, Schiraldi O, Stetler-Stevenson WG, Quaranta V. 1997 Induction of cell migration by matrix metalloprotease-2 cleavage of laminin-5. Science 277:225-228. [PubMed: 9211848]

Gibbins JR. 1978 Epithelial migration in organ culture. A morphological and time lapse cinematographic analysis of migrating stratified squamous epithelium. Pathology 10:207-218. [PubMed: 364387]

Gill SE, Parks WC. 2008 Metalloproteinases and their inhibitors: Regulators of wound healing. Int J Biochem Cell Biol 40:1334-1347. [PubMed: 18083622]

Greenlee KJ, Corry DB, Engler DA, Matsunami RK, Tessier P, Cook RG, Werb Z, Kheradmand F. 2006 Proteomic identification of in vivo substrates for matrix metalloproteinases 2 and 9 reveals a mechanism for resolution of inflammation. J Immunol 177:7312-7321. [PubMed: 17082650]

Greenlee KJ, Werb Z, Kheradmand F. 2007 Matrix metalloproteinases in lung: Multiple, multifarious, and multifaceted. Physiol Rev 87:69-98. [PubMed: 17237343]

Grenache DG, Zhang Z, Wells LE, Santoro SA, Davidson JM, Zutter MM. 2007 Wound healing in the a $2 \beta 1$ integrin-deficient mouse: Altered keratinocyte biology and dysregulated matrix metalloproteinase expression. J Invest Dermatol 127:455-466. [PubMed: 17068473]

Gross J, Lapiere CM. 1962 Collagenolytic activity in amphipian tissues: A tissue culture assay. Proc Natl Acad Sci USA 48:1014-1022. [PubMed: 13902219]

Guo L, Eisenman JR, Mahimkar RM, Peschon JJ, Paxton RJ, Black RA, Johnson RS. 2002 A proteomic approach for the identification of cell-surface proteins shed by metalloproteases. Mol Cell Proteomics 1:30-36. [PubMed: 12096138]

Gupton SL, Waterman-Storer CM. 2006 Spatiotemporal feedback between actomyosin and focaladhesion systems optimizes rapid cell migration. Cell 125:1361-1374. [PubMed: 16814721]

Hattori N, Mochizuki S, Kishi K, Nakajima T, Takaishi H, D’Armiento J, Okada Y. 2009 MMP-13 plays a role in keratinocyte migration, angiogenesis, and contraction in mouse skin wound healing. Am J Pathol 175:533-546. [PubMed: 19590036]

Holmbeck K, Bianco P, Caterina J, Yamada S, Kromer M, Kuznetsov SA, Mankani M, Robey PG, Poole AR, Pidoux I, Ward JM, Birkedal-Hansen H. 1999 MT1-MMP-deficient mice develop dwarfism, osteopenia, arthritis, and connective tissue disease due to inadequate collagen turnover. Cell 99:81-92. [PubMed: 10520996]

Hotary K, Allen E, Punturieri A, Yana I, Weiss SJ. 2000 Regulation of cell invasion and morphogenesis in a three-dimensional type I collagen matrix by membrane-type matrix metalloproteinases 1, 2 and 3. J Cell Biol 149: 1309-1323. [PubMed: 10851027]

Hotary KB, Allen ED, Brooks PC, Datta NS, Long MW, Weiss SJ. 2003 Membrane type I matrix metalloproteinase usurps tumor growth control imposed by the three-dimensional extracellular matrix. Cell 114:33-45. [PubMed: 12859896]

Hynes RO. 2002 Integrins: Bidirectional, allosteric signaling machines. Cell 110:673-687. [PubMed: 12297042]

Inoue M, Kratz G, Haegerstrand A, Ståhle-Bäckdahl M. 1995 Collagenase expression is rapidly induced in wound-edge keratinocytes after acute injury in human skin, persists during healing, and stops at re-epithelialization. J Invest Dermatol 104:479-483. [PubMed: 7706762] 
Kajita M, Itoh Y, Chiba T, Mori H, Okada A, Kinoh H, Seiki M. 2001 Membrane-type 1 matrix metalloproteinase cleaves CD44 and promotes cell migration. J Cell Biol 153:893-904. [PubMed: 11381077]

Kaverina I, Krylyshkina O, Small JV. 2002 Regulation of substrate adhesion dynamics during cell motility. Intern J Biochem Cell Biol 34:746-761.

Kenny HA, Kaur S, Coussens LM, Lengyel E. 2008 The initial steps of ovarian cancer cell metastasis are mediated by MMP-2 cleavage of vitronectin and fibronectin. J Clin Invest 118:1367-1379. [PubMed: 18340378]

Koshikawa N, Giannelli G, Cirulli V, Miyazaki K, Quaranta V. 2000 Role of cell surface metalloprotease MT1-MMP in epithelial cell migration over laminin-5. J Cell Biol 148:615-624. [PubMed: 10662785]

Krampert M, Bloch W, Sasaki T, Bugnon P, Rulicke T, Wolf E, Aumailley M, Parks WC, Werner S. 2004 Activities of the matrix metalloproteinase stromelysin-2 (MMP-10) in matrix degradation and keratinocyte organization in wounded skin. Mol Biol Cell 15:5242-5254. [PubMed: 15371548]

Krawczyk WS. 1971 A pattern of epidermal cell migration during wound healing. J Cell Biol 49:247263. [PubMed: 19866757]

Krengel S, Alexander M, Brinckmann J, Tronnier M. 2002 MMP-2, TIMP-2 and MT1-MMP are differentially expressed in lesional skin of melanocytic nevi and their expression is modulated by UVB-light. J Cutan Pathol 29:390-396. [PubMed: 12139633]

Kubo M, Van de Water L, Plantefaber LC, Mosesson MW, Simon M, Tonnesen MG, Taichman L, Clark RA. 2001 Fibrinogen and fibrin are anti-adhesive for keratinocytes: A mechanism for fibrin eschar slough during wound repair. J Invest Dermatol 117:1369-1381. [PubMed: 11886497]

Kure T, Chang JH, Kato T, Hernandez-Quintela E, Ye H, Lu PC, Matrisian LM, Gatinel D, Shapiro S, Gosheh F, Azar DT. 2003 Corneal neovascularization after excimer keratectomy wounds in matrilysin-deficient mice. Invest Ophthalmol Vis Sci 44:137-144. [PubMed: 12506066]

Kyriakides TR, Wulsin D, Skokos EA, Fleckman P, Pirrone A, Shipley JM, Senior RM, Bornstein P. 2009 Mice that lack matrix metalloproteinase-9 display delayed wound healing associated with delayed reepithelization and disordered collagen fibrillogenesis. Matrix Biol 28:65-73. [PubMed: 19379668]

Larsen PH, Wells JE, Stallcup WB, Opdenakker G, Yong VW. 2003 Matrix metalloproteinase-9 facilitates remyelination in part by processing the inhibitory NG2 proteoglycan. J Neurosci 23:11127-11135. [PubMed: 14657171]

Lauffenburger DA, Horwitz AF. 1996 Cell migration: A physically integrated molecular process. Cell 84:359-369. [PubMed: 8608589]

Lechapt-Zalcman E, Prulière-Escabasse V, Advenier D, Galiacy S, Charrière-Bertrand C, Coste A, Harf A, d'Ortho MP, Escudier E. 2006 Transforming growth factor-beta1 increases airway wound repair via MMP-2 upregulation: A new pathway for epithelial wound repair? Am J Physiol Lung Cell Mol Physiol 290:L1277-L1282. [PubMed: 16414983]

Lee JM, Dedhar S, Kalluri R, Thompson EW. 2006 The epithelial-mesenchymal transition: New insights in signaling, development, and disease. J Cell Biol 172:973-981. [PubMed: 16567498]

Legrand C, Gilles C, Zahm J-M, Polette M, Buisson A-C, Kaplan H, Birembaut P, Tournier J-M. 1999 Airway epithelial cell migration dynamics: MMP-9 role in cell-extracellular matrix remodeling. $\mathrm{J}$ Cell Biol 146:517-529. [PubMed: 10427102]

Levi E, Fridman R, Miao HQ, Ma YS, Yayon A, Vlodavsky I. 1996 Matrix metalloproteinase 2 releases active soluble ectodomain of fibroblast growth factor receptor 1. Proc Natl Acad Sci USA 93:7069-7074. [PubMed: 8692946]

Li S, Chow LH, Pickering JG. 2000 Cell surface-bound collagenase-1 and focal substrate degradation stimulate the rear release of motile vascular smooth muscle cells. J Biol Chem 275:35384-35392. [PubMed: 10948197]

Li Q, Park PW, Wilson CL, Parks WC. 2002 Matrilysin shedding of syndecan-1 regulates chemokine mobilization and transepithelial efflux of neutrophils in acute lung injury. Cell 111:635-646. [PubMed: 12464176] 
Lohi J, Wilson CL, Roby JD, Parks WC. 2001 Epilysin: A novel matrix metalloproteinase (MMP-28) expressed in testis and keratinocytes and in response to injury. J Biol Chem 276:10134-10144. [PubMed: 11121398]

Lu PC, Ye H, Maeda M, Azar DT. 1999 Immunolocalization and gene expression of matrilysin during corneal wound healing. Invest Ophthalmol Vis Sci 40:20-27. [PubMed: 9888422]

Madlener M, Parks WC, Werner S. 1998 Matrix metalloproteinases (MMPs) and their physiological inhibitors (TIMPs) are differentially regulated during excisional skin wound repair in mice. Exp Cell Res 242:201-211. [PubMed: 9665817]

Manicone AM, Huizar I, McGuire JK. 2009 Matrilysin (MMP-7) regulates anti-fibrotic and antiinflammatory pulmonary dendritic cells that express CD103 (aEb7-integrin). Am J Pathol (in press).

Massova I, Kotra LP, Fridman R, Mobashery S. 1998 Matrix metalloproteinases: Structures, evolution, and diversification. FASEB J 12:1075-1095. [PubMed: 9737711]

McCawley LJ, Matrisian LM. 2001 Matrix metalloproteinases: They're not just for matrix anymore. Curr Opin Cell Biol 13:534-540. [PubMed: 11544020]

McGuire JK, Li Q, Parks WC. 2003 Matrilysin (matrix metalloproteinase-7) mediates E-cadherin ectodomain shedding in injured lung epithelium. Am J Pathol 162:1831-1843. [PubMed: 12759241]

McQuibban GA, Gong JH, Tam EM, McCulloch CA, Clark-Lewis I, Overall CM. 2000 Inflammation dampened by gelatinase A cleavage of monocyte chemoattractant protein-3. Science 289:1202_ 1206. [PubMed: 10947989]

Mirastschijski U, Impola U, Karsdal MA, Saarialho-Kere U, Agren MS. 2002 Matrix metalloproteinase inhibitor BB-3103 unlike the serine proteinase inhibitor aprotinin abrogates epidermal healing of human skin wounds ex vivo. J Invest Dermatol 118:55-64. [PubMed: 11851876]

Mirastschijski U, Zhou Z, Rollman O, Tryggvason K, Agren M. 2004 Wound healing in membranetype-1 matrix metalloproteinase-deficient mice. J Invest Dermatol 123:600-602. [PubMed: 15304103]

Mohan R, Chintala SK, Jung JC, Villar WV, McCabe F, Russo LA, Lee Y, McCarthy BE, Wollenberg KR, Jester JV, Wang M, Welgus HG, Shipley JM, Senior RM, Fini ME. 2002 Matrix metalloproteinase gelatinase B (MMP-9) coordinates and effects epithelial regeneration. J Biol Chem 277:2065-2072. [PubMed: 11689563]

Montell DJ. 2008 Morphogenetic cell movements: Diversity from modular mechanical properties. Science 322:1502-1505. [PubMed: 19056976]

Nagavarapu U, Relloma K, Herron GS. 2002 Membrane type 1 matrix metalloproteinase regulates cellular invasiveness and survival in cutaneous epidermal cells. J Invest Dermatol 118:573-581. [PubMed: 11918701]

Netzel-Arnett S, Mitola DJ, Yamada SS, Chrysovergis K, Holmbeck K, Birkedal-Hansen H, Bugge TH. 2002 Collagen dissolution by keratinocytes requires cell surface plasminogen activation and matrix metalloproteinase activity. J Biol Chem 277:45154-45161. [PubMed: 12192005]

Nobes CD, Hall A. 1995 Rho, rac, and cdc42 GTPases regulate the assembly of multimolecular focal complexes associated with actin stress fibers, lamellipodia, and filopodia. Cell 81:53-62. [PubMed: 7536630]

Noe V, Fingleton B, Jacobs K, Crawford HC, Vermeulen S, Steelant W, Bruyneel E, Matrisian LM, Mareel M. 2001 Release of an invasion promoter E-cadherin fragment by matrilysin and stromelysin-1. J Cell Sci 114:111-118. [PubMed: 11112695]

Odland G, Ross R. 1968 Human wound repair. I. Epidermal regeneration. J Cell Biol 39:135-151. [PubMed: 5678445]

Okada A, Tomasetto C, Lutz Y, Bellocq J-P, Rio M-C, Basset P. 1997 Expression of matrix metalloproteinases during rat skin wound healing: Evidence that membrane type-1 matrix metalloproteinase is a stromal activator of pro-gelatinase A. J Cell Biol 137:67-78. [PubMed: 9105037]

Overall CM, Blobel CP. 2007 In search of partners: Linking extracellular proteases to substrates. Nat Rev Mol Cell Biol 8:245-257. [PubMed: 17299501] 
Page-McCaw A, Ewald AJ, Werb Z. 2007 Matrix metalloproteinases and the regulation of tissue remodelling. Nat Rev Mol Cell Biol 8:221-233. [PubMed: 17318226]

Parks WC. 2007 What is the alpha2beta1 integrin doing in the epidermis? J Invest Dermatol 127:264266. [PubMed: 17228304]

Parks WC, Wilson CL, Lopez-Boado YS. 2004 Matrix metalloproteinases as modulators of inflammation and innate immunity. Nat Rev Immunol 4:617-629. [PubMed: 15286728]

Pilcher BK, Dumin JA, Sudbeck BD, Krane SM, Welgus HG, Parks WC. 1997 The activity of collagenase-1 is required for keratinocyte migration on a type I collagen matrix. J Cell Biol 137:1445-1457. [PubMed: 9182674]

Powell WC, Fingleton B, Wilson CL, Boothby M, Matrisian LM. 1999 The metalloproteinase matrilysin proteolytically generates active soluble Fas ligand and potentiates epithelial cell apoptosis. Curr Biol 9:1441-1447. [PubMed: 10607586]

Ra HJ, Parks WC. 2007 Control of matrix metalloproteinase catalytic activity. Matrix Biol 26:587596. [PubMed: 17669641]

Ridley AJ, Schwartz MA, Burridge K, Firtel RA, Ginsberg MH, Borisy G, Parsons JT, Horwitz AR. 2003 Cell migration: Integrating signals from front to back. Science 302:1704-1709. [PubMed: 14657486]

Rowe RG, Weiss SJ. 2008 Breaching the basement membrane: Who, when and how? Trends Cell Biol 18:560-574. [PubMed: 18848450]

Saarialho-Kere UK, Kovacs SO, Pentland AP, Olerud J, Welgus HG, Parks WC. 1993 Cell-matrix interactions modulate interstitial collagenase expression by human keratinocytes actively involved in wound healing. J Clin Invest 92:2858-2866. [PubMed: 8254040]

Saarialho-Kere UK, Kovacs SO, Pentland AP, Parks WC, Welgus HG. 1994 Distinct populations of keratinocytes express stromelysin-1 and -2 in chronic wounds. J Clin Invest 94:79-88. [PubMed: 8040294]

Saarialho-Kere UK, Vaalamo M, Puolakkainen P, Airola K, Parks WC, Karjalainen-Lindsberg ML. 1996 Enhanced expression of matrilysin, collagenase, and stromelysin-1 in gastrointestinal ulcers. Am J Pathol 148:519-526. [PubMed: 8579114]

Saarialho-Kere U, Kerkela E, Jahkola T, Suomela S, Keski-Oja J, Lohi J. 2002 Epilysin (MMP-28) expression is associated with cell proliferation during epithelial repair. J Invest Dermatol 119:1421. [PubMed: 12164918]

Sabeh F, Li X, Saunders TL, Rowe RG, Weiss SJ. 2009a Secreted versus membrane-anchored collagenases: Relative roles in fibroblast-dependent collagenolysis and invasion. J Biol Chem 284:23001-23011. [PubMed: 19542530]

Sabeh F, Shimizu-Hirota R, Weiss SJ. 2009b Protease-dependent versus -independent cancer cell invasion programs: Three-dimensional amoeboid movement revisited. J Cell Biol 185:11-19. [PubMed: 19332889]

Seiki M 2002 The cell surface: The stage for matrix metalloproteinase regulation of migration. Curr Opin Cell Biol 14:624-632. [PubMed: 12231359]

Seomun Y, Kim JT, Joo CK. 2008 MMP-14 mediated MMP-9 expression is involved in TGF-beta1induced keratinocyte migration. J Cell Biochem 104:934-941. [PubMed: 18307173]

Shi J, Son MY, Yamada S, Szabova L, Kahan S, Chrysovergis K, Wolf L, Surmak A, Holmbeck K. 2008 Membrane-type MMPs enable extracellular matrix permissiveness and mesenchymal cell proliferation during embryogenesis. Dev Biol 313:196-209. [PubMed: 18022611]

Skoog T, Elomaa O, Pasonen-Seppanen SM, Forsberg S, Ahokas K, Jeskanen L, Parssinen J, Tiala I, Rollman O, Lohi J, Saarialho-Kere U. 2009 Matrix metalloproteinase-21 expression is associated with keratinocyte differentiation and upregulated by retinoic acid in $\mathrm{HaCaT}$ cells. J Invest Dermatol 129:119-130. [PubMed: 18633436]

Staatz WD, Rajpara SM, Wayner EA, Carter WG, Santoro SA. 1989 The membrane glycoprotein IaIIa (VLA-2) complex mediates the $\mathrm{Mg}^{+2}$-dependent adhesion of platelets to collagen. J Cell Biol 108:1917-1924. [PubMed: 2715183]

Stamenkovic I 2003 Extracellular matrix remodelling: The role of matrix metalloproteinases. J Pathol 200:448-464. [PubMed: 12845612] 
Stenn KS, Malhotra R. 1992 Epithelialization In: Cohen IK, Diegelmann RF, Linblad WJ, editors. Wound healing: Biochemical and clinical aspects. Philadelphia: W.B. Saunders Co pp 115-127.

Stepp MA, Liu Y, Pal-Ghosh S, Jurjus RA, Tadvalkar G, Sekaran A, LoSicco K, Jiang L, Larsen M, Li L, Yuspa SH. 2007 Reduced migration, altered matrix and enhanced TGFbetal signaling are signatures of mouse keratinocytes lacking Sdc1. J Cell Sci 120:2851-2863. [PubMed: 17666434]

Stetler-Stevenson WG, Yu AE. 2001 Proteases in invasion: Matrix metalloproteinases. Semin Cancer Biol 11:143-152. [PubMed: 11322833]

Sudbeck BD, Pilcher BK, Welgus HG, Parks WC. 1997 Induction and repression of collagenase-1 by keratinocytes is controlled by distinct components of different extracellular matrix compartments. J Biol Chem 272: 22103-22110. [PubMed: 9268353]

Surendran K, Simon TC, Liapis H, McGuire JK. 2004 Matrilysin (MMP-7) expression in renal tubular damage: Association with Wnt4. Kidney Int 65:2212-2222. [PubMed: 15149334]

Swee M, Wilson CL, Wang Y, McGuire JK, Parks WC. 2008 Matrix metalloproteinase-7 (matrilysin) controls neutrophil egress by generating chemokine gradients. J Leukoc Biol 83:1404-1412. [PubMed: 18334539]

Tam EM, Morrison CJ, Wu YI, Stack MS, Overall CM. 2004 Membrane protease proteomics: Isotopecoded affinity tag MS identification of undescribed MT1-matrix metalloproteinase substrates. Proc Natl Acad Sci USA 101:6917-6922. [PubMed: 15118097]

Ueda M, Gräf R, MacWilliams HK, Schliwa M, Euteneuer U. 1997 Centrosome positioning and directionality of cell movements. Proc Natl Acad Sci USA 94:9674-9678. [PubMed: 9275182]

Vaalamo M, Karjalainen-Lindsberg ML, Puolakkainen P, Kere J, Saarialho-Kere U. 1998 Distinct expression profiles of stromelysin-2 (MMP-10), collagenase-3 (MMP-13), macrophage metalloelastase (MMP-12), and tissue inhibitor of metalloproteinases-3 (TIMP-3) in intestinal ulcerations. Am J Pathol 152:1005-1014. [PubMed: 9546361]

Vaisar T, Kassim SY, Gomez IG, Green PS, Hargarten SA, Gough PJ, Parks WC, Wilson CL, Raines EW, Heinecke J. 2009 MMP-9 sheds the beta 2 integrin subunit (CD18) from macrophages. Mol Cell Proteomics 8:1044-1060. [PubMed: 19116209]

Van Lint P, Libert C. 2007 Chemokine and cytokine processing by matrix metalloproteinases and its effect on leukocyte migration and inflammation. J Leukoc Biol 82:1375-1381. [PubMed: 17709402]

Van Wart HE, Birkedal-Hansen H. 1990 The cysteine switch: A principle of regulation of metalloproteinase activity with potential applicability to the entire matrix metalloproteinase gene family. Proc Natl Acad Sci USA 87: 5578-5582. [PubMed: 2164689]

Velasco G, Pendas AM, Fueyo A, Knauper V, Murphy G, Lopez-Otin C. 1999 Cloning and characterization of human MMP-23, a new matrix metalloproteinase predominantly expressed in reproductive tissues and lacking conserved domains in other family members. J Biol Chem 274:4570-4576. [PubMed: 9988691]

Webb DJ, Parsons J, Horwitz AF. 2002 Adhesion assembly, disassembly and turnover in migrating cells-Over and over and over again. Nat Cell Biol 4: 97-100.

Wilhelm SM, Collier IE, Marmer BL, Eisen AZ, Grant GA, Goldberg GI. 1989 SV40-transformed human lung fibroblasts secrete a 92-kDa type IV collagenase which is identical to that secreted by normal human macrophages. J Biol Chem 264:17213-17221. [PubMed: 2551898]

Wilson CL, Ouellette AJ, Satchell DP, Ayabe T, López-Boado YS, Stratman JL, Hultgren SJ, Matrisian LM, Parks WC. 1999 Regulation of intestinal a-defensin activation by the metalloproteinase matrilysin in innate host defense. Science 286:113-117. [PubMed: 10506557]

Wroblewski LE, Noble PJ, Pagliocca A, Pritchard DM, Hart CA, Campbell F, Dodson AR, Dockray GJ, Varro A. 2003 Stimulation of MMP-7 (matrilysin) by Helicobacter pylori in human gastric epithelial cells: Role in epithelial cell migration. J Cell Sci 116:3017-3026. [PubMed: 12808021]

Yeaman C, Grindstaff KK, Nelson WJ. 1999 New perspectives on mechanisms involved in generating epithelial cell polarity. Physiol Rev 79:73-98. [PubMed: 9922368]

Zhou Z, Apte SS, Soininen R, Cao R, Baaklini GY, Rauser RW, Wang J, Cao Y, Tryggvason K. 2000 Impaired endochondral ossification and angiogenesis in mice deficient in membrane-type matrix metalloproteinase I. Proc Natl Acad Sci USA 97:4052-4057. [PubMed: 10737763] 
Zweers MC, Davidson JM, Pozzi A, Hallinger R, Janz K, Quondamatteo F, Leutgeb B, Krieg T, Eckes B. 2007 Integrin $\alpha 2 \beta 1$ is required for regulation of murine wound angiogenesis but is dispensable for re-epithelialization. J Invest Dermatol 127:467-478. [PubMed: 16977325] 


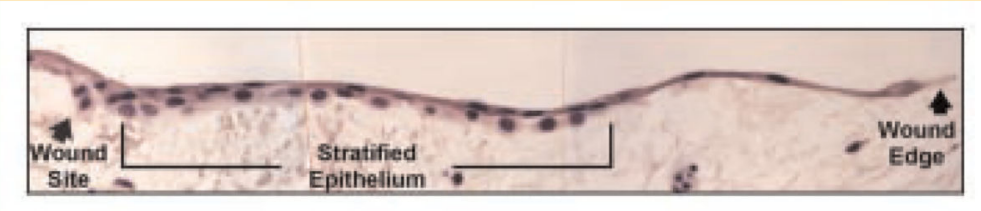

Fig. 1.

Morphology of the wound edge epithelium. Shown is the actively repairing epithelium at 5 days post-wounding of a human tracheal explant. Approaching the wound edge, the epithelial cells are squamated and stretched widely across the denuded lining. Behind the wound front, the epithelium is stratified over many cell diameters. However, the lining of intact airways is a simple (pseudostratified) epithelium; that is, basal surface of all cells lie on the basement membrane. In wounds, this normal histology is altered by reparative cells that "leap frog" over epithelial cells that had earlier moved over and covered the denuded tissue. These images suggest that much of the epithelial migration in wounds involves cellcell interactions rather than cell-matrix interactions. Reproduced with permission from the American Society for Clinical Investigation [Dunsmore et al., 1998]. 


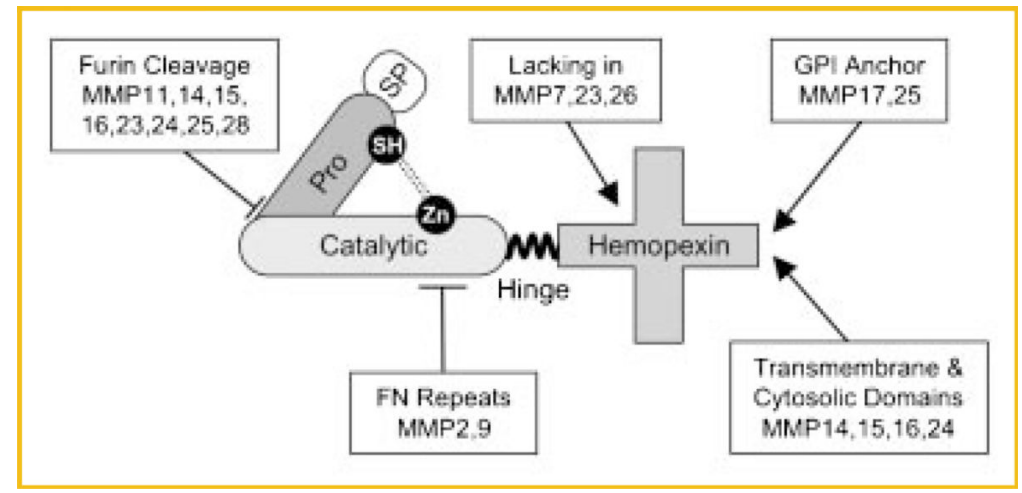

Fig. 2.

Domain structure of a typical MMP. The common motifs of MMPs are the pro- and catalytic domains. The prodomain of a typical MMP is about 80 amino acids and contains the consensus sequence PRCXXPD. The exception to this rule is MMP23, in which the critical cysteine is found within a distinct run of amino acids [Velasco et al., 1999]. The catalytic domain contains three conserved histidines in the sequence HEXXHXXGXXH, which ligate the active site $\mathrm{Zn}^{2+}$. Several MMPs have a furin recognition within the $\mathrm{C}$-terminal half of the prodomain allowing activation of zymogen by proprotein convertases within the secretion pathway. For most other MMPs, the activation mechanism is unknown [Ra and Parks, 2007]. As MMPs function in the extracellular space, they each have a signal peptide (SP), the exception again being MMP23, which has an N-terminal signal anchor. With the exceptions of MMP7, 23, and 26, MMPs have a flexible proline-rich hinge region and a hemopexin-like C-terminal domain, which functions in substrate recognition. Other additions include transmembrane and cytosolic domains to the membrane-type MMPs, a glycosylphosphatidylinositol (GPI) anchoring signal to MMP17 and 25, and gelatin-binding domains that resemble similar motifs in fibronectin (FN) in MMP2 and 9. 


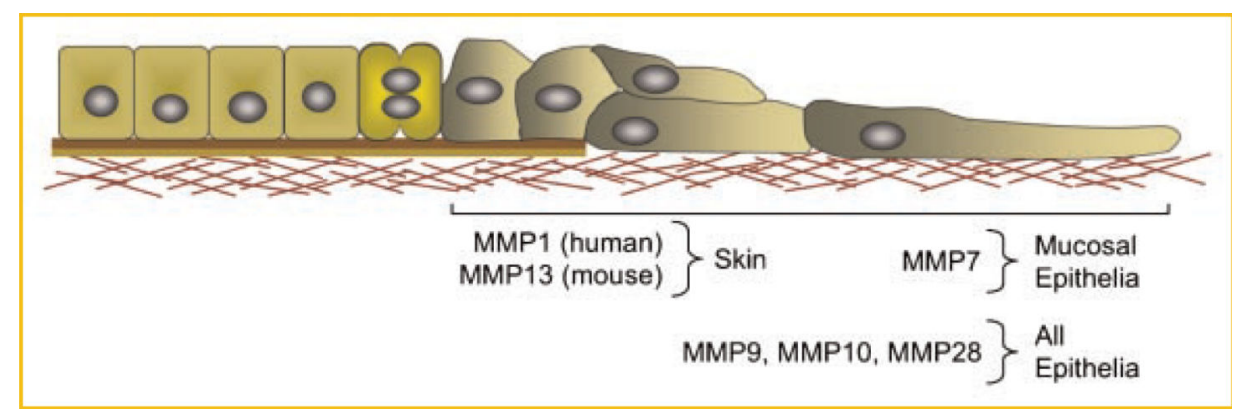

Fig. 3.

Patterns of MMP expression skin and mucosal wounds. The bi-color line under the intact and proliferating cells represents the basement membrane, and below that lies the interstitial matrix, which includes type I collagen. In skin, MMP1 is expressed by human keratinocytes and MMP13 is expressed by the analogous cell in mouse wounds. Although both collagenases promote re-epithelialization, it is not clear if they both function by an analogous mechanism. In mucosal epithelia, MMP7, which is not expressed in the wounded epidermis, is expressed at the wound front, and is required for efficient repair. In addition to these epithelial type-specific MMPs, other MMPs are expressed in all wounds. 


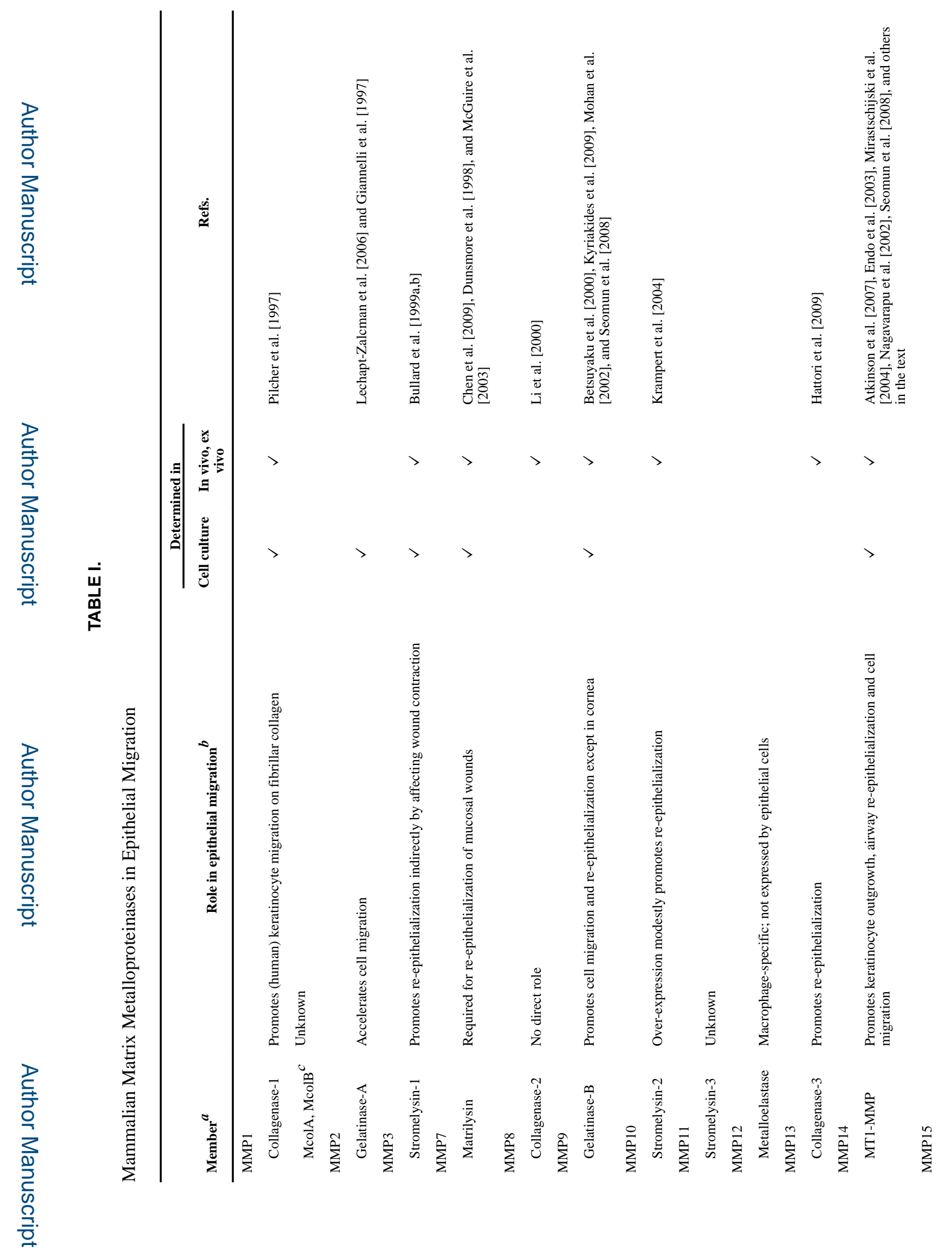

J Cell Biochem. Author manuscript; available in PMC 2019 March 29. 
Chen and Parks

Page 23

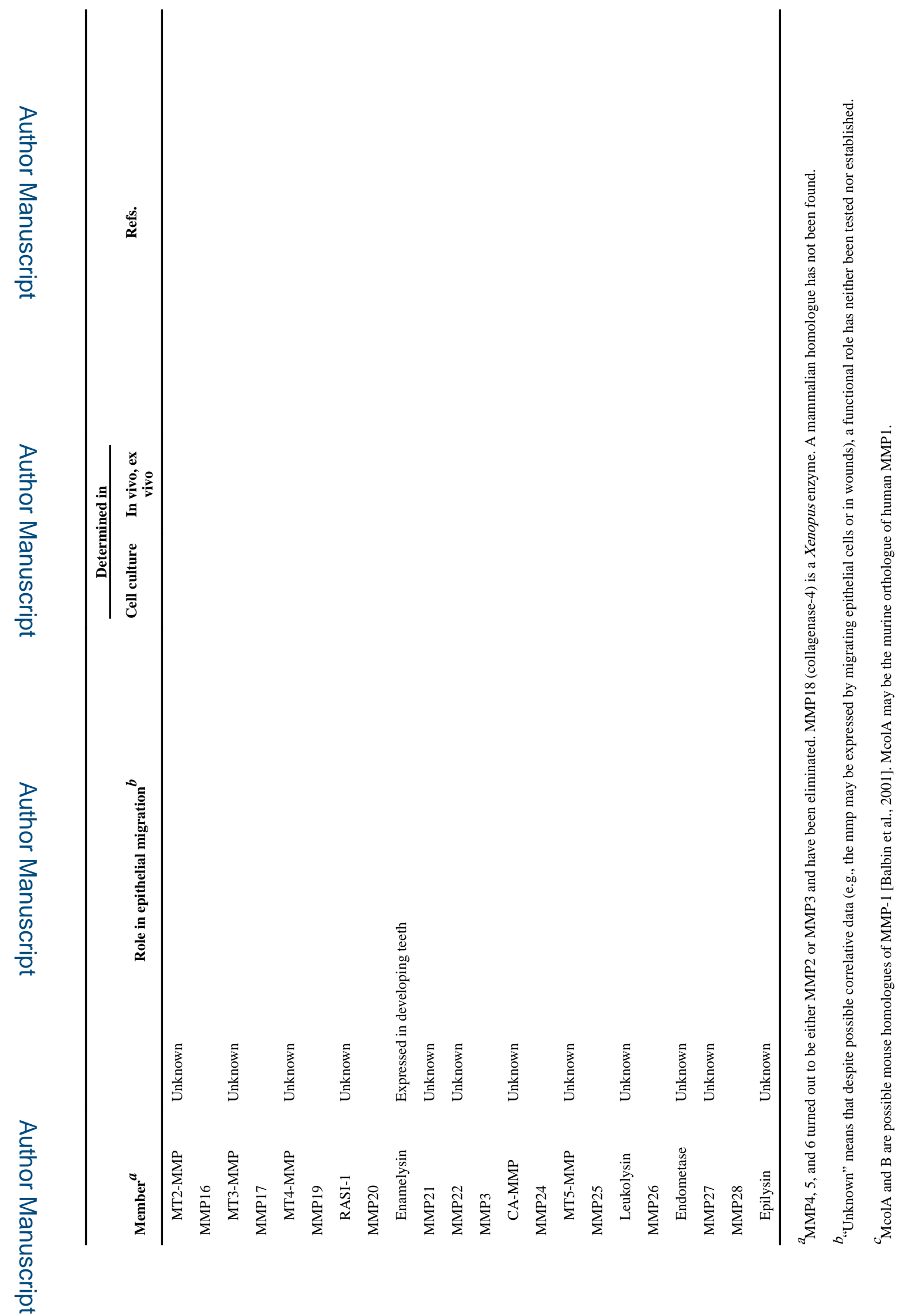

J Cell Biochem. Author manuscript; available in PMC 2019 March 29. 